座畏のまとめ $(607,608)$

\section{览玉 泰業医大薄生)}

607 : ベンゾィルクロライドおよびその整造中

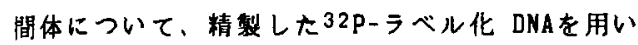
INAとの反応性を調へ、をの発癌性を比畩した成 維を狼告した。DNAとの強い反応が認められたの はベンゾトリクロライドであり、ベンゾィルクロ ライドがこれに次いだ。この反応には四icrosone が做量必要てNADPHは不必要である。反応後のピ ベリジン処理て塭基部位での切断が起こることよ り反応性が調ざられる訳であるが、短時間に簡便 に化学物筫とDNA の反応性が明らかになるため、 発癌性を予知する方法として今後の研究成績に期 待が持たれる。本発表に対して、in 、ivoでの例 の有無について質問があった。

608 : 多環芳香族炭化水素のニト口体は、自動 車排ガス中に見出される直接变異原物質の一つで あることより、汭・itroでの実䍉結果が多く報告 されている。演者らはハムスターの気管内投与実 䙲をおこない、ニトロピレン類の呼吸器官に対す

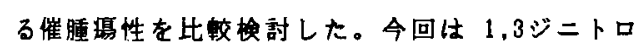
ピレン(DNP) (208 $\times 15$ 回)、1,6-DNP +1,8-DNP 混合物( $0.5 \mathrm{mg} \times 15$ 回) についての結果が報告され た。腫場発生率は 1,3-DNPて $40 \% 、 1,6$-DNP +

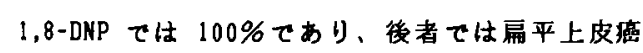
および腺癌できわめて悪性度が高かった。ニトロ ピレンを直按变異原性物質と緒言で述べたことに 対して、代碀物によるのではないかなどの䨘疑 応答がなされた。演者らは多理劳香族炭化水来な どの気管内杸与による実筑を従来より引き繶き実 施し、多くの成果を辄告してきているが、自動車 排ガス中の物貿に対する動物を用いての今後の害 解に期待したい。
609

\section{【有害有機物】}

エチレンテトラフルオロエチレン(共重合体)

の熱分解毒性について

（1）熱分解生成物と主要致死因子について

吉田康久, 渡辺美鈴, 山形裕土, 弘田俊行 (大阪医大衛生公衛)

河野公一（福井医大環境保健）

近年有機フッ素化学の進歩により種々のフッ素 樹脂が合成され，他の樹脂にみられない優九た性 質のために工業的に多量に製造使用されている。 これらのフッ素樹脂はその性質上しはしは耐熱限 界を越えて使用されることも多く、このとき発生 する熱分解ガス等の毒性の検討が常に必要とされ る。本研究では最近開発されたエチレンテトラ フルオロエチレン(ETFE) 共重合体について, 底面 温度を一定に制御できるステンレス製容器内にて 熱分解し，生成物をGC,GC-筫量分析などで解析す るとともに動物暴露陚験を行い主要致死因子を決 定することにより,本フッ素樹脂の製造および取 り扱い者における安全管理対策について検討した。

試料はか粒状のETFE共重合体であり,エチレンお よび4フッ化エチレンがそれそれ $48 \%, 6 フ ッ$ 化イン フテン約5\%の組成比を有する。

本試料を熱分解すると約 $260^{\circ} \mathrm{C}$ から搈融,分解が 始まり, $600^{\circ} \mathrm{C}$ 以上では急洀な热分解がみられた。 熱分解ガス中の有機成分を同定した結果，主な有 機成分として $4 フ ッ$ 化エチレン,フッ化ビニリテン, $6 フ ッ$ 化プロピレン,6フッ化インブテンなどが分 離された。フッ素樹脂の熱分解時にときに発生し 極めて毒性の高いオクトフルオロイソブテンの 生成は認められなかった。ETFE6gを減湿した空気 300L送気して熱分解した時フッ酸750ppm,6フッ化 イソブテンその他の有機性ガス合せて500ppmまた C0が700ppm検出された。この流度のガスを被検趿 物に15分間暴露させた坦合，1週間後に致命棌 $50 \%$ が瑟められたことから概算的致死䈨度 (ALC,15分 暴露 1 週間)は $6 \mathrm{~g} / 300 \mathrm{~L}$ よった。また熱分解ガス をガス洗浄形で洗気し，水溶性フッ化物主として フッ酸を除去した場合，その毒性が50\%低下するこ とから主要致死因子はフッ酸と考えられる。この フッ酸除去ガス中のC 0 湍度が $1450 \mathrm{ppm}, 6 フ ッ$ 化 イソブテンが450ppmあり,単独ALCと比較してこれ らの物質も2次的に致死因子として作用すること も示喛される。

エチレンテトラフルオロエチレン共重合体の熱 分解毒性を検討し，従来のフッ素樹脂の場合と同 様にフッ酸が主要致死因子となることを認めた。 さらに6フッ化インフテン,一酸化炭素の毒性作用 も指摘され,これらの成績を考虑して安全衙生対 策を行うべきものである。 
610
エチレンテトラフルオロエチレン（共重合体）
の熱分解毒性について

（2）熟分解生成物の生体影遙について

河野公一(福井医大環境保健)

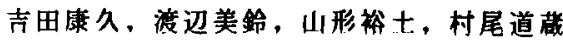
長家秀博 (大阪医大衛生公衛)

卓越した種々の特性から近年库業分野で広く使 用されているエチレンテトラフルオロエチレン （ETFE）共重合体について熟分解を行い,そのガス 状成分を動物に暴露させることにより生体への影 繁老解析し取り扱い者における健康管理对策につ いて検討した。

ETFE共重合体を熱電気的に底面温度を一定に制 御できる18-8ステンレス製容器内で空気中にて完 全分解温度 $\left(600^{\circ} \mathrm{C}\right)$ で熱分解させ,その生成物およ び既知の純䎦ガス成分についてラットを用いて 15 分間暴露させたのち7日間䙿察し,血液生化学検查 心電图所見などを検討した。

熱分解ガス暴露後まもなく呼㖟数が減少し四肢 の強直，立毛が見られ，全身のケイレンをきたし死 亡する例も舅察された。一般血液所見はガス暴露 後24-48時間において炎症像を思わせる白血球数 の増加が琹められた。赤血球数，へモグロビン量， ヘマトクリット值などは暴蹇前と比べてほとんど 変化がなかった。血清中フッ素惯度は暴露直後よ りすみやかに上昇し暴露後48時間まで高值を示し た。血清トータルカルシウム湿度は血清フッ素淇 度の変化に対応して暴露直後より減少を始め暴喜 後48時間にわたって低下の傾向を示した。

ナトリウム算度は暴露後一度上昇するものの， その後24時間まで隇少した。カリウム洗度は暴露

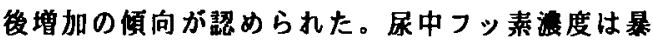
露後24時間尿において前值に比し10倍の排せつ量 が認められその後 1 週間にわたって排せつ量の增 加を鼠察した。心電图所見では暴露開始後より 徐係傾向を示し，心房湅動,房室ブックが琶めら れた。暴露䊏了後徐脈傾向は改善されるが種々の 阳性T波が出見し，その後死亡する例も兒察された。 以上の心電图所見は主として一酸化岸素によるも のと考えられるが各璉電解質による複合的な変化 に起因するものと思われる。 ETFE共重合体の熱分解生成物の生体への影整， 特に血清電解貝，一般血液像，心電图所見などを検 討し、これらの異常はガス暴露後の症状,死因をよ く反咉するものと考えられた。これらの粘果より フッ酸，一酸化炭素などによる全身隌害の可能性 を考虑して安全対策を行う必要が珰められた。
611

純系マウスにおける2,3,7,8一四塩化名 ベンゾダイオキシンの比較中毒学的研觉

長山淳哉、清原千香子、廣畑富雄 （九大医公衛）西住昌裕（佐賀医 大地域保健）垤江昭夫（産医大病

理）増田義人（第一薬大物理分析）

産業衛生あるいは産業中毒を考える場合、各種薬 凨の中毒作用を解明寸ると同時に、をれらの薬剂に 対する人間の感受性を解明することあまた重要であ ろう。これまでマウスを用いだ発ガン、催奇形性お るいは毒性実験の結果から、各種有害物質に対する 感受性が系統によって遗伝学的に異なることが報告 されている。この感受性はAh 遗伝子座によってコ ントロールされており、Ah 遺伝子座は芳香族炭化 水素水酸化䣼 (AHH) の活性を調節している。A

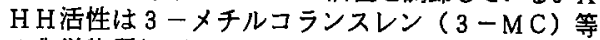
の化学物質処理によって誘導され活性が上昇するが、 マウスの場合、3-MC処理後 A H H 活性の上昇し ない系統 ( $\mathrm{AH} \mathrm{H}$ 非応答性系統) と上昇する系統

(A H H応答性系統) に遗伝学的に区別可能である。 有害物質に対する感受性は一般的にはA H H応答性 系統のほうがA H H非応答性系統より高いと考えら れている。てのような観点から、生活環境を污染し、 産業衛生上も問題である高毒性有機塩素化合物 2 , $3,7,8$ - 四塩化ダイベンゾダイオキシン (T C D D）の生体に対する作用を両系統のマウスを用い比 較検討した。これは人間の薬物に対する感受性を解 明するための 1 つのモデルである。

A H H 応答性系統のマウス (C57BL/6 N) およ びA H H非応答性系統のマウス (Qdj ; D D D) に 毎週 1 回 $30 \mu \mathrm{g} / \mathrm{kg}$ の T C D Dを I. P. 投与し、6 週目あるいは 12 週目で探血し、各藏器を探取した。 体重 - 臟器重量変化、血清生化学的検査 (GOT, GPT, 全蛋白量、全コレステロール量および過酸 化脂質量)および光顕あるいは電顕による病理組蟣 学的検查等の結果、いずれの観点からちA H H応答 性系統のマウスのほうがA H H非応答性系統のマウ スよりもTCD Dの中毒作用に対して感受性が曊著 に高いと判断された。

私共のてれまでの研究によれば日本人の集団です A H H 応答性が個々人によって異なっており、Ah 遗伝子活性調節の多様性が示唆されている。このこ とはまた、人間集団における薬剤への感受性の多橉 性も示唆しているわけで、この点での解明が待たれ る。（研究協力者：九大アニマルセンター半田純雄） 
座長のまとめ $(609 \sim 611)$

佐野 晴洋（京大医公衛）

609：熔融・成型性に優れるフッ素樹脂エチレン テトラフルオロエチレ゙ン（共重合体）を耐熱限界を 越えて使用する場合，発生する熱分解ガス・微粒子 成分の固定及びガス買露毒性試験を行ったものであ ろ。そして分解物の中フッ酸，6フッ化イソブテン， COの書性作用が指摘された。

610：上記 フッ素樹脂共重合体熱分解物貝のラッ トへの影望を調へたところ，血清 $\mathrm{F}$ 灙度は $3 \mathrm{~h}$ 後最 高値，48 h 後に元に戻り，血清総 $\mathrm{C} \mathrm{a}$ は暴轞直後 より，48h r に加け低下し， $\mathrm{N}$ a 婊度は一度上昇 して減少し，K港度は直ちに上昇， $8 \mathrm{~h} \mathrm{r}$ 後で最高 で $48 \mathrm{~h} \mathrm{r}$ 後もなお高值を示す。熱分解時に生ずる COガスの影暗と，上記の電解質の変化が複合的に 作用して，心電図にも変化が出ると報告した。

611：ある種の有害物筫が体内に侵入すると，チ トクロームP 450 䤃素系により，解毒されたり，逆 に毒性の強いるのに転換する場合がある。後者の場 合は発ガン，催奇性やより強い毒性出現につながる。 一般にこの様な後者の応答をよくするマウスC 57 B L / $6 \mathrm{~N}$ と非応答系D D T 用いて夫々にT C D $\mathrm{D}$ を投与して, 体重, 臓器重量変化, 生化学的変化, 病理組織学的変化を調べてみると, 何れの場合すC 57 系統のマゥスに重症の中毒症状が観察された。 このととは，薬剤に対する感受性の多様性が遗伝子 的に存在しうることを示唆するものであり，との様 な観点加ら産業滆生・産業中毒を考える必要性をの べ注目をひいた。
612

有害因子の複合影整に関する細胞遭伝学的研究

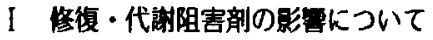

森本兼黙 三浦邦彦 小泉 明 (東京大医公徫)

人間が生活境境或は産業現場等で種々の有害摆境因子 に暴露する际には、単一のagent に対する算露のみなら

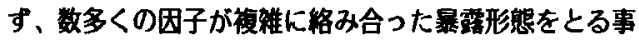
が予想される。従って今後の座業衛生学に於ける有害因 子の生体影照評価に際しても複效要因の交絡閶係を定量 的に解析していく必要があるが、本研究ではその様大問 題にアプローチする際のモデルとして、その作用が既に

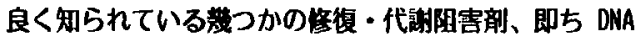
polymerase $\alpha$ を阻害するとされている Cytosine arabinoside (ara-C) 及ర゙Aphidicoline (APC) 、poly (ADP)ribose polymerasek対して阻客作用を示す 3-Aminobenzamide (3AB) 、バクテリアに於ける topoisomerase 活性を阻害する事が知られているNovobiocin

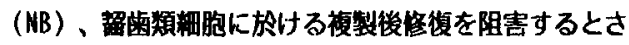
れているCaffeine、虫白合成阻害剤として知られている Cycloheximide (CHX)，DNA 合成阻害㓣として知られ るHydroxyurea（HU）及び核酸の頪仪物空でONA 代勘阻 害剂であるFluorodeoxyuridine (FUdR) を取りあげ、放 射综或は化学物質により誘発されたDNA 賃害及びその鉴 復過程がこれらの物翼の共存によりどの栏な等飾作用を 受けるかを娭楌した。

その結果ara-C の後処理により ${ }^{137}$ Cs - $\gamma$ 線 (2 Gy)

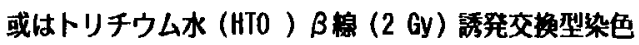

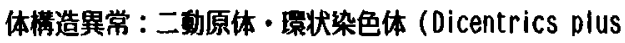
rings；D+R）頻度は夫々粎2倍及び4倍に上昇し、又、 Caffeine並びに3-ABは共に放射皛（ $\gamma$ 被及ひ山TO $\beta$ 線）

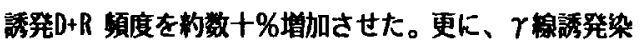
色体傋造異常に対するara-Cの作用を群しく検討した所、

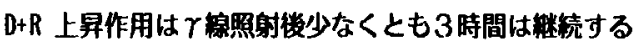
事が明らかとなったのみならす、と楾照射前のara-Cの 短時間処理によってもD+R 須度は有意に上昇する事が示 された。又、DNA 偒害性物質として知られるmitomycin C $\left(3 \times 10^{-8} \mathrm{H}\right)$ 誘哞姉妹染色分体交换 (Sister Chro-

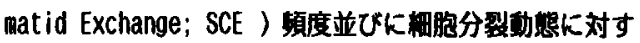

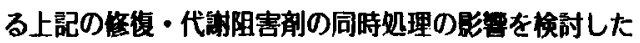
所、SCE 須度の大きな変助が钼察されたが、その傾向は 必ずしも構造異常の隹飾作用で覞察された㑯向とは一致 しておらず、又細胞分裂㫑態に関してはara-C が梅めて 強い細胞増殖阻害作用を示したのに対し、HUは逆に絊胞 增殖促進作用を示した。

今後は以上の结果を種々の実唤系を用いて更に追試 ・ 礁認していく必要があるものと思われる。 
613

リンパ芽球様細胞株の産業徨生への応用について

I 細胞周期の検討

\section{三浦邦彦 森本兼量 小泉 明 (東京大医公衛)}

末梢リンパ球染色体変異を指標とした有害摆境因子暴 露に対するmonitoringは、既に一部の産業現場等で実用 化されつつある。しかしながらprimary のリンパ球は探 取が容易である半面、通常の培羔法では長期的な培善が 不可能であり、又湅胞の倲結保存の方法も一皯的ではな い事から、对象者の長期に亘る染色体感受性の変化を钼 察する目的には必ずしも商した系であるとは言い難い。 一方、末梢血より分噰されたリンパ球をEpstein-Barr (EB) ウィルスでtransform する事により得られるリン パ芽球槏湖胞株 (Iymphoblastoid cell line; LBL )は、 樹立並びに涷結保存が容易であり、且つ榯立後数か月以 内であれば粎代を続けても核型が安定であるとされてい る事から長期に亘るpopulation monitoring に於いて新 しい可能性を提供するものと言えよう。ところで、染色 体レベルの感受性を娭討する腙に近年多く採用されてい る姉妹染色分体交换 (Sister Chromatid Exchange; SCE)

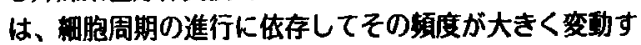
る事が既に報告されている為、細胞増㥀動態の検討はSC E を用いたpopulation monitoring の研究にも必須の倹 討事項であると思われる。そこで本研究では、将来LBL を産業現場に於けるmoni toringに応用する為の基硉的 一夕を得る事を目的にLBL の增殖标態・細胞周期の検討 を行なった。その结果、最初に4 $410^{5}$ /mI の婊度で嬏 種されたLBL を72時間培羡した翼合には細胞数は䄪 $10^{6}$ /mI に增加した事から、LBL の集団としての倍化時間は 约40〜50時間である事が推定された。又蛍光ギムサ法を 用いた姉妹染色分体分染法により個々の梱胞に於ける梱 胞周期を検討した所、primary のリンパ球の构12時間に 対して、 LBL は新20時間の緗胞周期を有している事が示 された。今後は以上の知見を基础に、化学物筫員荷時の

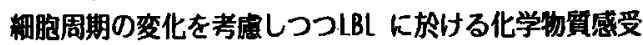
性の検討を行ない、LBL を用いた実際の産業現場に於け るmonitoringを試みて行きたい。
座長のまとめ $(612,613)$

$$
\text { 長山 淳臷（九大医公霜） }
$$

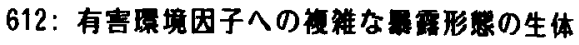
影䇺を定量的に解析するためのモデルとして本 研究が行われた。放射裸あるいは化学物筫によ

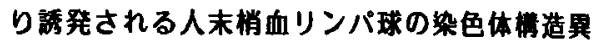
常あるいは姉妹染色分体交埙の須度が厔々の代 期阻害剂処理によってどのような侮作用を受 けるかが検时された。结果として，代时阻害都

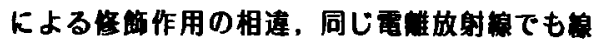
源による终篇作用の差異，およひ里霞の時图的 factorの重要性等が坡告された。種々のagent による複合影雷の解析は非常に重要であるが， きわめて图篗な分矛である。今倓の成果が期特 される。

613：長期間の培意と棝桔保存が可能であるリ

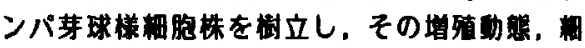
周周期および姉妹染色分体交换 (SCE) 㖽度 が調べられた。primaryのリンバ球湅胞で得ら

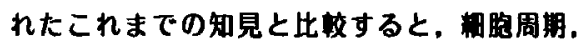
堌殖的態には多少の相遧が钼宗されたものの， basel ineSCE覑度についてはほほ同一の詰果 が㧹られた。これは有害因子に对する染色体し ベルの人間の感受性を長期に亘ってnonitoring するための基磪的研究洁果である。今後, 研究 がどのように進展するのか楽しみである。 
614

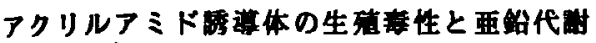
(マウス)

坂本原子，橋本和夫（金沢大医衙生）

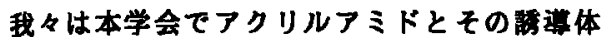

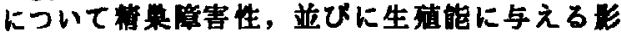

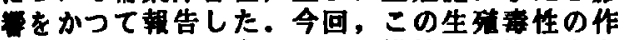
用战序を明らかにするため，婎性生萑能の荧吉

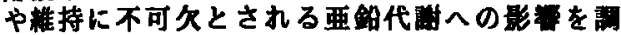
た.

実馀に用いた禖尊体は，アクリルアミド（A Mと殿)，N一ハイドロオキシメチルAM（H AM) , NーメチルAM ( N M A) , N , N ' ーメチレンピスAM (M B A) で，各部速体を 椎マウスに急性，又は贯性投与した传，65 Z n

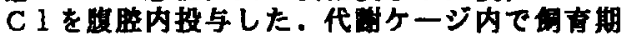
間中， $\mathrm{Z} n-65$ の尿中排せつ量を即定し，5

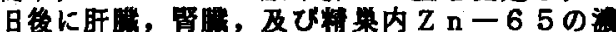

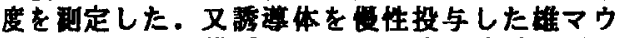
スを用いて，正労崔マウスとの交配夷后を行い，

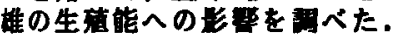

急性時の Z n-65 展中排せつ量については，

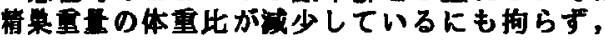
その层中排せつ量に変化は無かった。一方，杪

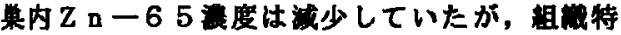
異性はみられない。

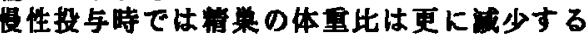

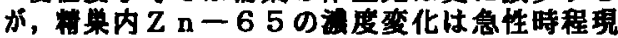
れず，かつ増加の㑯向にあった。Z $\mathrm{n}-65$ の 叔中排せつ量に间しては一致した傾向がなく， NMAで有意に淢少し，HMA，MABで逆に 增加していた。

情菓におけるこれらの現象は誘盖体投与停止

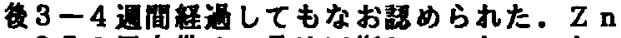
-65の尿中排世つ量は回得していた。マウス

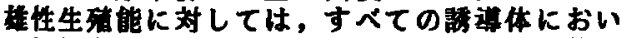

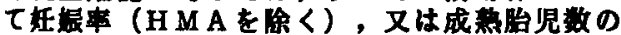
娍少と㖟収胎児数の增加があった。

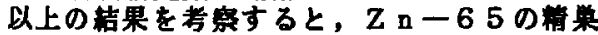
内漊度が急性時に波少する機序については不明 であるが，得性時で增加するのは急性時の成少 を回推させる二防御反底とも考えられる。

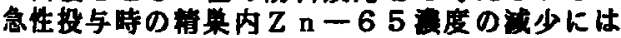
細待特異性がみられなかったが，传性，及び回 偍時の Z n-65浱度の増加には特奥性がみら

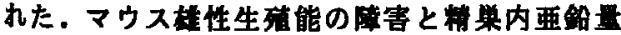

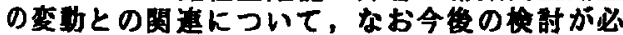
要と考える。
615

オルトアミノフェノールによるメトへモグロビンの 生成楮序

酒井徤江、緒方正名（岡山大医公衛）

[目的]オルトアミノフェノール $(\mathrm{O}-\mathrm{AP})$ は染 料合成の中間体として使用されている。呼吸器より 大量に吸収されるとメトへモグロビン血症を起す。 O-APとへモグロビン（H b ）液をインキュベー トすることによりメトへモグロビン（met Hb）を 生成することが報告されている。この際、過酸化水 素の関与にういて、ヒトHbに対する力夕ラーゼ添 加の影䇺および正常マウスとアカタラセミアマウス 血液との比較検討を行った。

[実駼方法] H b 液の調製：ヒト赤血球よりAebiの 方法で H b 液を調製した。マウス $\mathrm{H}$ b液はマウスよ り採血した血液を洗浄後、蒸留水で溶血し遠心分離 でコーストを除き上清液を $\mathrm{Hb}$ b液とした。 $\mathrm{Hb}$ 灌度 は0.6mg/mlとした。met $\mathrm{H}$ bの䐉定: ジメチルスル ホキシドに溶解した O-APをH b 液に添加し37 C で反応させmet $\mathrm{H}$ b生成に伴う630nm における波長 の吸収を、経時的に测定した。

[結果] (1) 0-AP添加後の、時間経過に伴う met $\mathrm{H}$ b 生成：O-AP添加後 1 分間の初速度仙

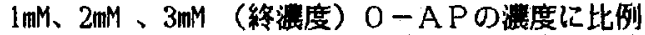
して速くなった。またOーAP添加後約 3分間は速 やかなmet $\mathrm{H}$ bの生成が見られた。（2）力夕ラー ゼによるmet $\mathrm{H}$ b生成への影箱： 0 -APとH b 液 の中に500u/ml カタラーゼを添加するとmet H b 生 成の抑制が見られた。その抑制効果はいずれも約15 分まてにOーAPのmet H b 生成の約50\% の㧕制が 見ら机た。力夕ラーゼ添加 3分後のmet $\mathrm{H}$ b生成は 反応時間の対数に比例して增加が見られた。(3) 正常マウスおよびアカタラセミアマウス溶血渡にお けるmet $\mathrm{Hb}$ b生成: $0.5 \mathrm{mMO}$ - APを各々のマウス $\mathrm{H} \mathrm{b}$ 液に添加すると、カタラーゼをほとんど合まな いアカタラセミアマウスの方が正常マウスの場合の 約1.5 倍のmet $\mathrm{H}$ b生成が見られた。

[考察]人における0-APの有害作用にメトへモ グロビン血症などがある。ヒト血液とマウス血液を 用いて実呀を行った。 H b 液にOーAPを添加後、 630nm での吸光度のすみやかな増加が見られ、met $\mathrm{Hb}$ b生成が見られた。1 分間の初速度は0-AP の濞度に比例して速くなった。またカタラーゼの添 加によりmet $\mathrm{H}$ b生成の抑制が見られ、アカ夕ラセ ミアマウスのH b 液は正常マウスのそれより、met $\mathrm{H}$ b生成量は約 1.5 倍であった。これは力夕ラーゼ 活性の差によるものと考えられる。以上のことから O-APがH bに作用して生成した過酸化水素が、 $\mathrm{H}$ bを酸化して目et $\mathrm{H}$ bを生成したものと推定され る。

[結論]赤血球内にはかなり多量のカタラーゼなど の酥素が合まれているので、これがSODなど共に 過酸化水素を中間体とするmet $\mathrm{H}$ b 生成の抑制因子 の一つとして倒らいていると考えられる。今後、力 タラーゼ漄とmet $\mathrm{Hb}$ b生成との量的関係と共にS ODの影慗を検討する予定である。 
座長のまとめ $(614,615)$

桜井治庨大 医・街生公街)

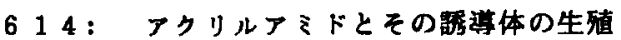
輁性メカニズムを明らかにするためにマウスで

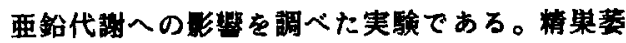
綃は急性、慢性を問わず明暞であるが、覀鉛の 湅巣内取り迄みは急生投与時に減少し、侵性投 与時に增加していた。垔鉛取り込みの格槽、垔

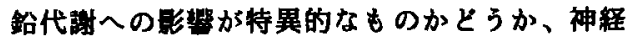
毒性を発現する投与量との比較などの贔問があ

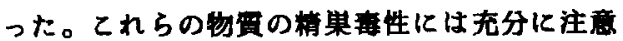
を払わなければならず今後の研究の進展が期待 されるととろである。

615 ： オルトアミノフェノールによるメト へモグロビン生成に腙しての $\mathrm{H}_{2} \mathrm{O}_{2}$ の成与につ いてアカタラセミアマウスを用いるなと興味あ ろ実験である。佐野、川西ら（京大）から、こ の周辺の反応機楼については最近の研究により 紐かい所までわかって来ていろので、それらを ふまれてより樑く切り込んで倽しいとコメント があった。竹村 (宓䓌医大) から、 $\beta$ かーフチ

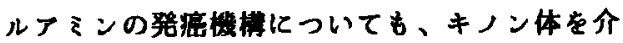

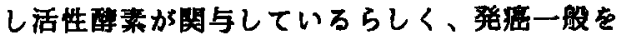
合め広傹な用味にながる研究領域であると追 加があった。
616

機械工場における切削油・灯油の使用と皮窝障害

枈田英治，竹内康浩，久永直見 小野雄一郎（名大医街生）

早川律子（名大分院皮有科）

切削油・灯油を使用する機械工坦の学何者の皮此 障害に関する調查を行なった。調查したのは自牞機 栈等を製造する機械メーカー、およびその関連会社 の合わせて 3 工㧹（従業員数：A工㧹・男 165名、 女 115名、B工場・男 294名、女 203名、C工坦・ 男1081名、女 224名) である。これらの工堨の金風 加工職堨では、水溶性、不水溶性の切削油を使用、 さらにB工捍では切削油に加え、灯油も使用されて いる。これら 3 工㧹の従業員の定期健㽷喰断の際に 用いた自覚症状調查票より皮度症状と切削油使用と の関連について調べた。さらに 3 工坦の中で切削油 ・灯油を使用する金属加工職場の労倾者．男子 100 名（A工坦・17名、B工鸤・21名、C工坦・62名）、 女子41名（A工坦·23名、B工堨·16名，C工坦・ 2 名）に对し、問診によって皮症症状の既往、切削 油・灯油等の使用状況、保讙具等の対策等を用へた 上、皮消科医による手の診察を行なった。自觉症状 調查票の回收率は男子72.9\% 、女子75.3\% であった。

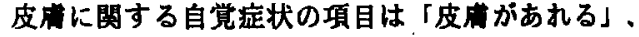
「皮福がかぶれる」の 2 項目があり、両項目におい て、男女ともに切削油使用者が非使用者に対して症

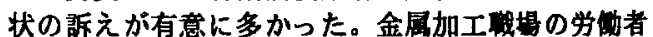
に対する問診の結果、各工坦の男女の50 91\%に発赤、 强症などの皮店障害の既往を琵めた。㱏状は慢性的 に続いたり、緥り返したりするものもあり、春、夏 に堌悪する例が多かった。切削油は 3 工坦合わせて 水溶性が10種類、不水溶性が19種類使用されていた。 保護具は手使用が最も多く、他に保讙クリーム、 マスク、保護メガネが使用されていた。皮科医に よる手の診察では男子で41 90\%、女子で50〜75\%に杠 斑、落屑をはじめとする異常所見を琹めた。また。 水溶性切削油、不水溶性切削油、灯油のうちいすれ かを使用し、他を同時に使用していない労的者を选 び、それらの皮留所見を比較してみると、男子で不 水溶任切刿油使用者に対し、灯油使用者に有意に多 くの異常所見を認めた。また。同じく男子で異常所 見のうち紅斑、落屑を呈する者は灯油使用者が水㴦 性、不水溶性切削油使用者に划して有意に多かった。 今後、切削油成分の改善、切削工程の密閉自就化 保護具着用の数底、保讙クリームの開発等の対策を 一層すすめること、そして同時に、金風加工乵场の 労的者の皮漳害の実態をさらに明らかにすること が必要である。 
617

㿟酸ビニル墈脂エマルジョン接著㸮使用者に発生し た再生不良性唄血の 4 症例

久永直見、竹内廉浩、小野椎一郎

岩田全充、枈田英治（名大医衙生）

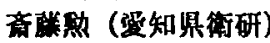

原田规章（强媛大医公衛）

吉見真一、上野尚（宇部始立病完）

酶酸ビニル㯕脂エマルジョン接竡剂（以下醀ビ接 者制）は、朴工、淑工等に広く性われ、今までのと ころ比校的弱毒性と考えられてた。ところが著者

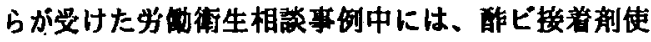

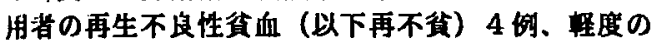
汹血球減少 1 例が含まれていた。本報では、これら の征例を䊀介し、今後の参考としたい。

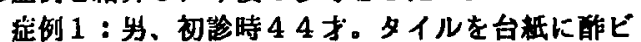

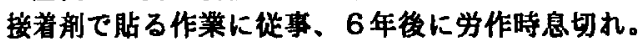

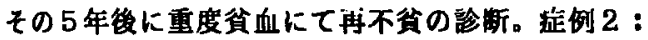

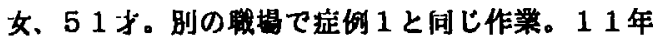
後に栄作時息切九。モの 2 年役に重度会血にて再不 貟の晾䉼。症侧 3 : 男、42才。ドライクリーニン

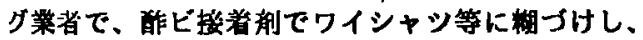
アイロンがけ.8年後に出血镇向、重度莫血が等に

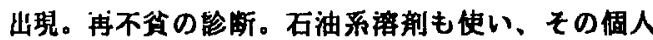

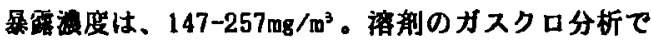

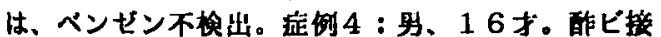

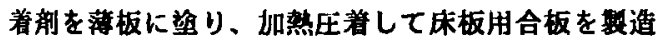
する作羓。7 ケ月後に出血顷向出胃。その 3 个月後 に重度食血にて再不算の朗断。本例は、ユリアメラ

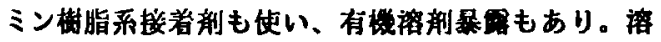
剂個人暴露溜度は、トルエン0.3-3.3PPM，キシレン 3.2-7.3PPM。应例 5 : 男、56才。造的浙で工作

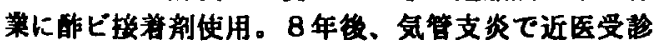

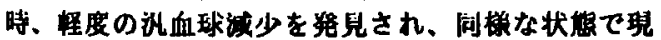
在に至る (WBC2500-4500, RBC364-445 万。, Hb 10. 9-13

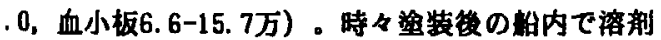

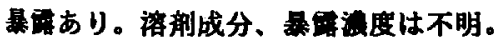

発症前の菜都服用歷は、提例 1、3、4 はなし、

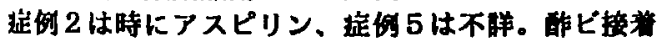
新月間他用量は3-40Kg、使用日数は3-6 日/掘、使

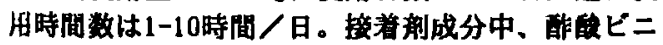
ルポリマー（モノマー少贯含有）とポリピニルアル

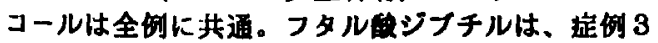

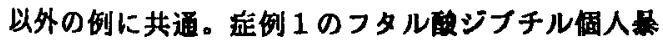

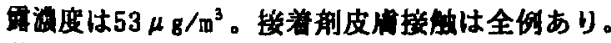
著省らの知る筑明では、酢ビ接啫刹による再不鿓の 报告はみられないが、他にも问榚な拉例がある可能 性があり、今後注意が必哭と思われる。
座長のまとめ $(616,617)$

\section{吉田 康久（大阪医大衛生公衛）}

616：切削作業に使用する切削油，灯油による 皮虚障害は，演者らが指摘するように作業者の 大多数,ときに90\%までが経鋻し，切実な問題と なっている。しかし，本作業が普辺的であるだけ に，従来かえって調查，報告される機会が少なか った。本研究でその実態が明確にされるととも に，特に灯油使用例に紅斑，落屑等の発症が多い ことが指摘されることに意義がある。質問とし ては,保讙クリーム,カネクタンの種類について， $\mathrm{E}, \mathrm{A}$ の特に被膜の強いものを使用しているがそ の効果は調查していない,また,色素沈着につい ては特に才イル使用例に多かったが，使用期間 も強く影響することなどが回答された。

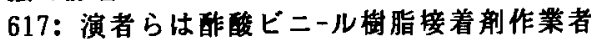
5名に，我国で初めて再生不良性顡血等の登症を 認めるとともに，またここれら作業者が同時に匴 い有機溶剖暴露，または医菜品㵵取もなかった ことを調查している。さらに質問として,外国 においてもこのような事例はなく，また，加熟に よる熱分解ガスの影繁についてもPattyがベン ゼンの発生を認めていることはあるが，本作業 工程では熱処理されていないことを答えている。 したがって,これら酢酸ビニール榯脂接着剂は使 用量が桎めて多いこともあり,今後とも本研究 が発展して因果関係が明確にされることが要望 される。 
港㴔何役作業者における

急性バラニトロクロルベンゼン中毒例

（1）発生状況と症状経遇

$$
\begin{aligned}
& \text { 田䰜武夫（大限公愽研）原一郎（関西医大） } \\
& \text { 南 正康（産医研） }
\end{aligned}
$$

1984年 7月 5日、大臤南港において、バラニトロクロ ルベンゼン(PNCB) の荷役作莱中、同物领による急性中毒 か発生した。我々は、この中毒の梌断などに参加協力し、 メトへモグロビン(Met-Hb) 书よび尿中ジアゾ反応陽性物 留 (ジアゾ物页) を経日的に测定した。 作業者は19人て、服装は長袖上衣、長ズボン、保琵帽、 安全靮、ゴム引き手袋てあったか、署さのため璄まくり をしたり、上衣を脱いて肌着のまま作革した者もあった。 作業は、フレーク状のPNCBの25kg入り紙袋8000袋を、 50-100袋つつ、はしけ上て網状のモッコに手㯖みし、ク レーンで吊上げ、本船船倉内におろし、これを手作莱で 整理するちのて、9 時一15時（昼休み、12時一13時）の 間行った。この際破袋が生じ、PNCBが上方から降ってく ることが再三あった。な书紙袋は、内からポリエチレン、 林、セロハン、紙、紙、の5重届でった。

糟荷作業開始約30分後から、顔、腹部、大腿、手など がピリピリし、11時半頃 2名、15時頃 5名、㷌宅後 4名 が異常を訴え、計11名か入院した。星食も殆どの者が食 欲がなく、茶ずけにしたり、残したりした。このうち 1

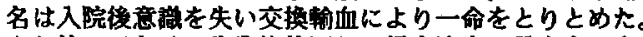
また他の 1名は、作菜後飲酒して帰宅途中、電車中で意

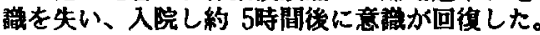
入院患者10名の主な自莧症状はチアノーゼ、䭪重、食

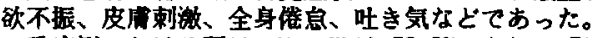
重症例における翌日のMet-Hbは $58.8 \%$ てあり、5日後 には72.0\% に達し危第状熊となった。交換輸血 $(4000 \mathrm{ml})$ により $38.8 \%$ に低下し、意樴も回復した。ハインッ小体 も二日徙から樰度に增加し、ほとんど1000\% に達した。 シアソ物驾は、暴活当日約 $5.6 \mathrm{mg} / \mathrm{mg}$ creatinine（正 常上限俌の約10倍) を示し、経日的に隇少した。 Met-Hbが活正常に復したのは、18日後でり、この 時点てはジアゾ物馆も正常レベルに低下した。 中および㪕症例ては裂日のMet-Hbは、6.9-23.3\%で り、全員が正常に復したのは18日捘でった。ジアゾ物 留は、数名を除きほ济同槏の傾向て経日的に減少した。

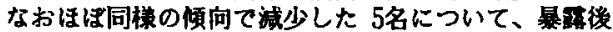
5-9日の值から求めたジアゾ物啠の生物学的半減期の平 均値は3.92(SD:0.60) 日てあった。

まとめ

今回の事例は、破袋し、落下、飛散したPNCBが経気道 的ならびに経皮的に体内に吸収されて、急性中毒が生じ たものと考えられるか、皮展や友類への付着加多加たた ことから経皮吸収の程度が大きったものと判断される。 尿中ジアソ物的の测定によって、PNCBの暴路評価を行 うことが可能てあった。

今回の事故は、作莱者にその毒性についての十分な䂱 明かなされず、また不十分な設借て、安易に取报ったた めに生じたすのでる。今僟、港湾何役作萧において有 害物を取扱う埸合の包装や作菜方法、撖偖等の改善、安 全㽞生救育の微底などの対策が必要と考る。

この報告において、Met-Hbの暴事5日目の交换制欰以 後の值、ハインツ小体、へマトクリット、およひ網赤血 球の测定は、大阪船員保除病院て実施されたものておる。

\section{永利 博美 (三菱化成·黒渏)}

618：有害性の教育なし、真夏の炎天下の力仕事 作業衣不適、包装紙袋の強度不適等の諸要因か湩な って、かなり重度の中毒を起した例てある。重症例 では、ハインツ小体かほほ 100\%にみられたため交 換输血により救命されたものてある。政問、追加事 項も治㓐法に関するものか多く、従来最も効果あり とされてきたメチレンブルーの投与については、注 射剂が手しにくいことと発得性の疑いがあること から投与しなかったということでる。その他の治

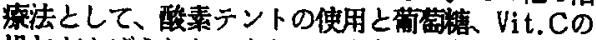
投与があげられた。またこのような工業製品有害物 の中毒にさいして、治療にあたる一般病院の対応に とまどいが多く、中毒情報センターの篮借の必要性 か強調された。

619: 発表中止 
620

TDI 曝露モルモットにおける肺病理学的検討 一TDI曝露による呼吸機能への影整評価 (6)-
伊藉哲也、三木知子、吉田 勉、立川壮一
島 正吾、（保健衛生大医公衛）
栗田秀樹、（保健衛生大医衛生）
笠原正男、（保健徫生大医第 1 病理）

Tluene-di-isocyanate(TDI) は, occupational immunologic lung diseases の起因物質として徉来よ り知られており、喘息は代表的疾患であるが、近年 我国では過敏性肺资等の発症が報告されている。我 々は、これらの肺疾患の発生を考慮してモルモット に対するTDI 曝露実験を行い、肺組織への影蘍につ いて娭討したので報告する。

[方法] 実験動物には Hartley系モルモット（雄 3 50〜400g、コントロール群 3 匹、曝露群 5 匹) を使 用し、曝露箱中の TDI濃度が0.1 0.2ppmとなる曝 露装置を自作して実験を行なった。曝露時間は7時 間／日、5日/週、实験期間は昭和59年 6 月18日〜 9月18日とした。鼻茾、くしゃみ、間歇的咳等の他 覚的所見を 1 時間毎に記録し、曝露開始 3 ケ月後に 屠殺、肺の病理組織学的変化を検討した。

[結果並びに考察] モルモットの曝露開始後の体重

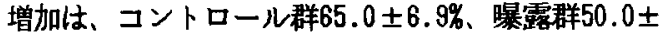
10.0\% であり曝露群が低值化する㑯向を認めた。13 週後の最終体重を比較してみると、曝露群はコント ロール群より低值であり有意差が認められた。曝露 群の他覚的所見では、曝露後早いもので $2 \sim 3$ 日、 遅いものでも2週後にはす心゙てに鼻计、くしゃみ、 間歇的咳の出現を認めた。しかし、上記症状出現時 に俧診上ではラ音を藅取できず、本実鈳では、TDI による喘息を発生せしめたとの確証は得られなかっ た。曝露群における肺の肉眼的所見ては、肺は两側 とも全て仅白色調を呈して気腫状に腫大し、部分的 に充実性領域が存在し、割面では赫䄍色を呈する所 見がみられた。影微鏡的所見としては、兩側全葉に 気管支周辺の間質から肺胞領域に向って中隔の肥昌 がみられ、中隔は增生する間葉系細胞と組維球から 成り、少数のリンパ球・形質細胞の混在を認めた。 中陾の血管床は减少㑯向を示し、肺胞も無気肺状を 呈していた。気管支粘膜はやや過形成であるが、管 内には资症性細胞は認められなかった。以上の所見 は、間質性肺炎像ことにUIPを示唆する所見であっ た。また他の部分では、多発するリンパ淲胞力苑め られた。コントロール群では、肉眼的、組䋨学的に も著変がなかった。今回の実験において、病理組禨 学的には間質性肺资像の所見を得たが、今挠疫血 清学的検討等を行いこれらについて明確にしてゆき たいと考える。
621

ぜん息様症状既往T DI暴露作業者に関する研究

$$
\begin{aligned}
& \text { 大前和幸 桜井治彦 東 敏昭 照屋浩司 } \\
& \text { (慶応大医衛生公衛) }
\end{aligned}
$$

1981・1983年に実施したTDI淂露作業者に対 する健康調查において睍出された、TDI丵露に 起因すると考えられるぜん息様症状を経験した現 T D I 作業者 (以下経験者) と、経験のないT D 1 作業者（以下未経験者）にっいて比較検討した。

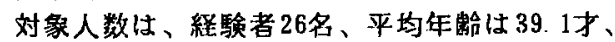
平均 T D I 晎露期間は 12.4年であり、ぜん息榢発 作は殆んと゚が就度前後・夜間の激しい咳を主徵と する Late reactionで、初T D I 粰露から初発作 までの期間は3な月以内が最も多かった。初発作 時の暴露状態は、大部分通常作業濃度であり、半 数以上が医師による治療をうけていた。

経験者と未経験者49名の㭔吸機能を、フローボ リンウームテストにより比較すると、唡群に有蜜 な差はなく、1981・1983年の2 年間の呼吸椎能変動 にも差はなかったが、 TDI作業前後の呼吸機能 変動は経験者で大きいことが観察され、我々が別 のTDI作業者集団就対として実施した調查結 果上同し知見が得られた。経験者のうち7名は初 発作以後も時々やや高い浱度のTDIに暴露した 場合に呼吸器症状を呈すると訴え、この群の呼吸 機能はやや低下を示した。また5名は初発作前に 風邪をひいていたと答え、この群の呼吸機能は体 調良好であったと答れた19名に比べやや低下を示 し、現在も時々㭔吸器症状を呈すると訴える率は 有意に高く、初 T D I 暴露から初発作までの期閵 が長いことが観察された。

以上の結果上り、一度 T D I 亿対する耐性它獲 得しTDI作業を持続でき乃作業者の呼吸機能は、 集団としては低下していないてとが明らかとなっ た。しかし気道の過敏性或いは反応性は、生理的、

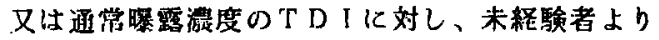
高いことが示唆された。また、観察人数は少ない か、、呼吸器症状在繰り返方埸合や、T D I 過敏性 については問題のないと考えられる長期 T DI蝶 露者で、風邪などが誘因となり通常のT D I 暴露 浱度でぜん息様発作をおこした場合に活、呼吸柲

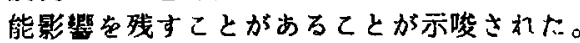


座長のまとめ $(620,621)$

$$
\text { 竹本 泰一郎（長崎大医公衛） }
$$

620： T D I の呼吸器影響について、モル モットでの樭露実験で間質性肺炎一いわゆる過 敏性肺资の所見がみられたと報告された。人の T D I 喘息でのアレルギ一の関与と動物実験で の過敏性肺炎との対応につんて蜇疑が交された。

621 ： 調查時点で平均濃度 $5 \mathrm{ppb}$ 以下の TD I 取扱い作業です、喘息様発作経験者では 未経験者より作業前後の呼吸機能の変動が大を く、生理的あるいは T D I 賕簬に刘する気道反 応性が高まっている可能性が報告された。対象 者の職種や作業条件、ピーク濃度存ど主として 作業環境濃度と呼吸機能所見との関連について 過去の贈露状態を含めて討論された。
622

しいたけ取报い作菜者のアレルギー症状

$$
\begin{aligned}
& \text { 青野裕士 荒記俊一 西園晃 (大分医大 } \\
& \text { 公衛衛生) } \\
& \text { 中村晋 (大分大学保健管理センター) }
\end{aligned}
$$

しいたけの集荷・橃別・包装を行なう作業 者（以下，集選作業者之略），路地裁培作丵 者，八ウ不栽培作棠者（男 454 人，女1 4 7人）にアンケート調查を行ない，各看のて レルギー症状の出現頻度を比敦した。言た，

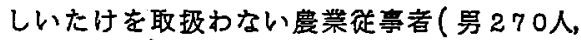
女297人)を対照群とした。

以下の結杲定得た。(1)工愐目のてレルギ 一症状のうち工項目以上が作叢中に出現する と回答した者は，集迩作丵者が51\%と最も 高かった。(2)女子の集㴍作業者の“早レル デー症状”の出現率は全年令跸叙で対照群よ り有意倍加った $(p<0.05)$ 。(3)男子の

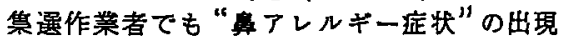
率が对照群より有意に高加った（ $\mathrm{p}<0.05 ） 。$ (4)女子の集選作学者（全員）の“钼フ、レルギ 一症状”の出現率は“アレルギー性結膜咨症 状”およひ“気管支・肺アレルギー症状”より 有意に高加，た $(\mathrm{p}<0.05)$ 。(5)女子の集 遥作業者が1項目以上のてレルキー症状を訴

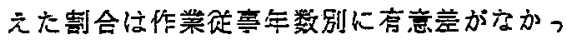
た $(\mathrm{p}>0.05)$ 。ガーゼマスク着用者と非 着用者との間にも有意差がなかった。

以上より，しいたけによる各種のフレルギ 一疾患の早期発見と予防对策を進める上で， 罳フレルギー症状の有無をチェックすることが 重要と考えられた。 